графическое развитие Республики Беларусь и сопредельных стран: Сборник статей. Серия «Демография. Социология. Экономика». Т. 3, № 2. - Москва; Минск: АЛЬТИОРА ФОРТЕ, 2017. - C. 89-98.

7. Тихонова, Л. Е. Экспорт образовательных услуг Беларуси: тенденции развития и география потоков / Л. Е. Тихонова, Л. В. Фокеева, Н. А. Кормильчик // Вестник РУДН. Серия: Экономика. — 2017. - Т. 25. № 1. - С. 54-62.

8. Рытов, А. В. Учебная миграция в Республике Беларусь и экспорт образовательных услуг / / А. В. Рытов, Л. В. Фокеева // Беларусь в современном мире: материалы XVII Междунар. науч. конф., посвящ. 97-летию образования Белорус. гос. ун-та, Минск, 26 окт. 2018 г.. - Минск: БГУ, 2018. - С. 370-372.

9. Рытов, А. В. Факторы учебной миграции в Республике Беларусь: результаты социологического опроса / А. В. Рытов, Л. В. Фокеева // Беларусь в современном мире: материалы XVII Междунар. науч. конф., посвящ. 97-летию образования Белорус. гос. ун-та, Минск, 26 окт. 2018 г. - Минск: БГУ, 2018. - С. 372-374.

10. Масленкова, Е. В. Перспективы образовательной миграции в Республике Беларусь: результаты экспертного опроса // Беларусь в современном мире: материалы XVII Междунар. науч. конф., посвящ. 97-летию образования Белорус. гос. ун-та, Минск, 26 окт. 2018 г. - Минск: БГУ, 2018 - С. 366-368.

11. Дорожная карта мероприятий по реализации программы «Экспорт Беларуси» на 2016-2020 годы: утв. постановлением Правительства Респ. Беларусь, 21 марта 2016 г. [Электронный ресурс] // Республиканская конфедерация предпринимательства. - Режим доступа: <http://rce.by/images/Дорожная_карта-21-03-16ч.doc>. - Дата доступа: 20.05.2018.

12. Концептуальные подходы к развитию системы образования Республики Беларусь до 2020 года и на перспективу до 2030 года; проект № 742 от 29 нояб. 2017 г. / Мин-во образ. Респ. Беларусь. - Минск, 2017. - 16 с.

13. Концепция развития экспорта образовательных услуг в рамках сотрудничества Республики Беларусь с иностранными государствами в 2018-2020 годы [Электронный ресурс] // БелТА. - 01.02.2018. - Режим доступа: <http://www.belta.by/society/view/vbelarusi-razrabotana-kontseptsija-razvitija-eksporta-uslug-v-oblasti-obrazovanija-na-2018-2020gody-287523-2018/> — Дата доступа: 22.10.2019.

\title{
POLITICAL CULTURE IN THE BALTIC STATES
}

\author{
Joakim Ekman \\ Södertörn University, \\ Alfred Nobels allé 7, 14189 Huddinge, Stockholm, Sweden, joakim.ekman@sh.se
}

Drawing on an original 2014 public opinion survey, this paper offers a brief overview of contemporary political orientations in Estonia, Latvia and Lithuania. Looking specifically at performace-related system support and attitudes towards democracy, the paper demonstrates significant cross-national as well as ethnic attitudinal differences in the region. Support for democracy does not seem to be overly strong in the Baltic states, but the key finding is that public support for democracy is still comparatively stronger than support for authoritarian rule. This is tentatively good news: as long as support for non-democratic regime alternatives does not exceed support for a democratic polity, democracy may be deemed to have sufficient legitimacy among citizens, and the risk of a democratic breakdown in the Baltic states must be regarded as insignificant.

Key words: public opinion, Baltic states, ethnic minority, political culture, democracy.

\section{ПОЛИТИЧЕСКАЯ КУЛЬТУРА В ПРИБАЛТИЙСКИХ СТРАНАХ}

\author{
Йоахим Экман \\ Сёдерторнский университет, \\ 7, пр. Альфреда Нобеля 14189 Худинге, Стокгольм, Швеция, joakim.ekman@sh.se
}

В статье предлагается обзор существующих политических тенденций в Эстонии, Латвии и Литве на основе проведенного в 2014 г. опроса общественного мнения. В частности, 
проанализирована поддержка обществом системы осуществления власти и отношение общества к демократии. Сделан вывод о том, что настроения населения региона имеют значительные кросс-национальные и этнические различия. Поддержка демократии не является исключительной характеристикой Прибалтики, однако отмечается динамика в росте поддержки обществом именно демократического стиля управления по сравнению с авторитарным. И это положительная тенденция: если настроения на поддержку альтернатив недемократического режима слабее поддержки основ демократии, то такая демократия может считаться легитимной среди граждан, что обеспечивает устойчивость Прибалтики.

Ключевые слова: общественное мнение, Прибалтийские государства, этническое меньшинство, политическая культура, демократия.

Introduction. Drawing on public opinion surveys is a straightforward way for political and social scientists to make assessments of the political culture in different countries, that is, citizens' values, attitudes and orientations related to the political system. How do ordinary people perceive the general development of their own country? How much trust is there in the government, in the parliament, and other political and societal institutions? This brief overview provides a snapshot of contemporary political orientations in the Baltic region.

Previous studies have demonstrated significant differences in political orientations between the titular populations and the Russian-speaking minorities in the region. Duvold (2006) for example, has shown that the different ethnic communities differ in their views on democracy and support for democratic institutions (Rose 2005; Ehin 2007; Lühiste 2013; 2008). We are thus well advised not to neglect attitudinal differences between the different ethnic groups in the present analysis.

The opinion data used in this paper was collected as part of a research project at Södertörn University, Sweden, funded by the Foundation for Baltic and East European Studies, Stockholm: European Values under attack? Democracy, Disatisfaction and Minority Rights in the Baltic States. In the spring of 2014, a series of polls were conducted among the majority populations and the ethnic minorities in Estonia, Latvia and Lithuania. In each country, around 1,000 people from the majority populations were included, alongside about 500 people from the different ethnic minority groups (here referred to as 'Russian-speakers').

Political dissatisfaction and ethnic divides. More than 30 years have passed since the days of the Singing revolution and the Baltic Way - the spectacular massive civil resistance campaigns that eventually led to the restoration of national independence for the three Baltic states, formally in 1991. The 'post-Soviet' status, however, did not stop the countries from standing out early on as the most developed of the former USSR republics. Especially the period from 2000 up until 2007 — with substantial economic reforms, foreign investments, and fast growth of GDP - earned the countries a new label: the 'Baltic Tigers'. Estonia in particular stood out as the most successful of the three countries. According to conventional wisdom (Almond and Verba 1980; Norris 1999), we should expect public assessments of economic as well as political performance to reflect the actual socioeconomic development, across time and across countries. We will start our overview by looking at the cross-national pattern of generalised system support.

Table 1 maps out the respondents' evaluation of the present state of affairs in the country in which they live, compared to previous historical eras. The respondents were asked: 'Thinking about the modern history of (this country) — in the 20th and 21st centuries - when would you say (this country) has been best off?' The response options were: in the interwar era; during the Soviet era (1940-1991); from the restoration of independence up until EU-membership (1991-2004); and today/present time (since 2004 and onwards). 
Table 1. When was this country best off? (\%)

\begin{tabular}{|c|c|c|c|c|c|c|c|}
\hline \multirow{2}{*}{ Period } & \multicolumn{2}{|c|}{ Estonia } & \multicolumn{2}{|c|}{ Latvia } & \multicolumn{2}{|c|}{ Lithuania } & \multirow[t]{2}{*}{ Mean } \\
\hline & $\begin{array}{l}\text { Maj } \\
\text { ority }\end{array}$ & $\begin{array}{l}\text { Min } \\
\text { ority }\end{array}$ & $\begin{array}{l}\text { Maj } \\
\text { ority }\end{array}$ & $\begin{array}{l}\text { Min } \\
\text { ority }\end{array}$ & $\begin{array}{l}\text { Maj } \\
\text { ority }\end{array}$ & $\begin{array}{l}\text { Min } \\
\text { ority }\end{array}$ & \\
\hline Interwar era & 20 & 2 & 31 & 14 & 7 & 3 & 13 \\
\hline Soviet era & 11 & 56 & 27 & 66 & 35 & 59 & 42 \\
\hline 1991 to 2004 & 31 & 20 & 22 & 13 & 25 & 18 & 22 \\
\hline Present time & 38 & 21 & 19 & 7 & 33 & 20 & 23 \\
\hline
\end{tabular}

Source: Baltic Barometer (2014). The most common response option has been highlighted in each column. $\mathrm{N}=1500$ in each country.

Table 1 basically documents a relative lack of confidence in the contemporary (democratic) era throughout the region. Starting with the majority populations, it is only in Estonia where a relative majority ( 38 per cent) opts for the present situation as the best time for the own country. In Lithuania, we find almost as many who feel that the present situation is preferable (33 per cent) as those who feel that the Soviet era was the best time ( 35 per cent). In Latvia, only 19 per cent agree that the present time is the best period in the modern history of the country; rather, the most common response option is actually the interwar era (31 per cent), possibly reflecting a widespread notion of the interwar era as a time of state-building and strong leaders (Gerner and Hedlund 1993: 57-58). Another 27 per cent of ethnic Latvians opt for the Soviet era as the best time.

Looking at the attitudinal differences between the groups in Table 1, a clear ethnic divide may be observed. In all three countries, the decidedly most popular response among the Russian-speaking minorities is the Soviet era. Differences are significant: where about 60 per cent of the minorities in the region think that the Soviet era was the best time, only 11 per cent of ethnic Estonians agree, alongside 27 per cent of ethnic Latvians and 35 per cent of ethnic Lithuanians. Thus, the minority groups seem to be consistently more dissatisfied than the majority groups with the situation in their own country after independence from the Soviet Union.

The patterns documented in in Table 1 may be partly be explained with reference to post-EU accession socioeconomic developments in the region. In 2008-2009, the global financial crisis that swept over Europe hit the Baltic states particularly hard. In Estonia, the economy shrunk by some 20 per cent from early 2008 to late 2009, and unemployment rose from 4.1 per cent (2007) to almost 20 per cent (2010). However, Estonia eventually recovered and was able to join the Euro-zone in 1 January 2011, successfully meeting all the criteria of the European Stability and Growth Pact.

Lithuania and, in particular, Latvia found themselves in a more difficult position. In Latvia, GDP contracted by 4.2 per cent in 2008, and shrank by a further 18.0 per cent in 2009. Needless to say, the economic crisis hit society hard, and the country had to rely on the International Monetary Fund (IMF) to reduce the budget deficit (Klein, Ozolina and Rostoks 2011: 34). The economic crisis was less severe in Lithuania, but it made an impact here as well: increasing emigration, swelling public debt and increasing energy prices remained high on the political agenda in Lithuania in the wake of the financial crisis (Jurkynas 2011). The political elites accepted the social costs and chose to cut back sharply on government spending. In practice, the households thus payed the bill, in the form of significantly reduced wages, increased unemployment and deteriorating pensions. Health care was put on a diet. The idea was that the cuts would reduce production costs and that the countries would consequently attract for- 
eign investment and increase exports, and thus bring about a recovery of the economy. The policy worked, in the sense that already in 2010 one could see a recovery and economic growth. Unemployment fell again, and the growth of GDP continued (cf. Duvold et al. 2019). In Estonia and Lithuania, the unemployment rate of the total population stood in 2019 at about 4-6 per cent respectively. In Latvia, the situation was slightly worse, especially among young people: youth employment in Latvia in 2017 was estimated to be as high as 17 per cent (World Migration Report 2018).

Political dissatifaction in the Baltic region may also be gauged from demographic statistics. All three countries have experienced negative population growth in recent decades. Particularly since the countries joined the EU in 2004, people have at an alarming rate been emigrating to seek their fortune elsewhere, not the least in the UK, Ireland, Norway and Germany. The negative population growth has been most noticeable in Latvia and Lithuania. In 2000, Latvia's population stood at 2.38 million. Two decades later, it had dropped by some 18 per cent. In Lithuania, the corresponding figure is 17.5 per cent. The situation was less severe in Estonia, which presently has a population of some 1.3 million (in 2019). Many Estonians work in Finland without fully emigrating. By 2017 some 200,00 Estonians, 375,000 Latvians and 600,000 Lithuanians were estimated to be emigrants (World Migration Report 2018).

Democratic orientations. Here, we have highlighted popular discontent and potential ethnic conflicts in the Baltic states (Table 1). What then are the implications for democratic stability in the Baltic region? The theoretical approach in the present paper draws on post-war research on political culture (Almond and Verba 1980), which is based on the assumption that a stable political system requires citizens who support the fundamental values and institutions that form the core of the political system (Easton 1965; Linz and Stepan 1996; Diamond, 1999; Rose et al. 1998). The underlying assumption is that a political system that lacks public support will not work properly, or at worst, completely collapse. The collapse of the GDR in the autumn of 1989 and the Soviet Union in 1991 could be said to be examples of such system breakdowns.

In the light of the empirical findings above (Table 1), one may ask if the Baltic democracies enjoy the kind of support from their citizens (and non-citizens, for that matter) that they need. Can democracy be taken for granted, in the years to come? In the public opinion data we utilize in this overview, we have one measure specifically designed to tap support for democracy as a principle or an ideal, i.e. as the most appropriate form of government (Table 2). Respondents are confronted with three statements, and are asked to pick the one they agree with the most: 'Democracy is preferable to any other kind of government'; 'Under some circumstances, an authoritarian government can be preferable to a democratic one'; or 'For people like me, it does not matter whether we have a democratic or a non-democratic regime'.

Attitudes towards democracy and non-democracy (\%)

Table 2.

\begin{tabular}{lcccccr} 
& \multicolumn{2}{c}{ Estonia } & \multicolumn{2}{c}{ Latvia } & \multicolumn{2}{c}{ Lithuania } \\
& Majority & Minority & Majority & Minority & Majority & Minority \\
$\begin{array}{l}\text { Democracy is always } \\
\text { preferable }\end{array}$ & 53 & 41 & 43 & 38 & 48 & 36 \\
$\begin{array}{l}\text { Authoritarian rule may } \\
\text { be accepted }\end{array}$ & 18 & 24 & 35 & 35 & 19 & 23 \\
$\begin{array}{l}\text { Indifferent to someone } \\
\text { like me }\end{array}$ & 25 & 32 & 21 & 24 & 17 & 25
\end{tabular}


Source: Baltic Barometer (2014). N = 1500 in each country.

The strongest support for democracy is found among the majority populations in Estonia and Lithuania, where an average of 51 per cent agree with the statement that democracy is always preferable (Table 2). In Latvia, public support for democracy is lower, with around 43 per cent among the majority population and 38 per cent among the Russian-speaking minority. In all three countries, the pattern is basically the same: the minority groups are slightly less likely to express support for democracy, and slightly more likely than the majority groups to express support for a non-democratic regime alternative. In Latvia, such (conditional) support for authoritarian governance is particularly high: around 35 per cent among the majority population and the Russian-speaking minority alike.

Table 2 also demonstrates that quite a few of the respondents feel that it simply does not matter if you have a democratic or a non-democratic government. Again, it is the minority respondents who are the most likely to agree with such an assertion, in all three countries (32 per in Estonia, 24 per cent in Latvia, and 25 per cent in Lithuania). In Lithuania, as many as 16 per cent of all respondents failed to provide an answer to the question about regime preferences.

Conclusions. Overall, Table 2 does not depict a region characterized by a strong democratic culture, quite the contrary. However, this does not necessarily mean that people in general will abandon democracy in the years to come, not even in the face of widespread political dissatisfaction. Support for democracy does not seem to be overly strong in the Baltic states, but the key finding here is that public support for democracy is still comparatively stronger than support for authoritarian rule (cf. Rose et al. 1998; Mattes and Bratton 2007). In fact, among all the population groups under review in Table 2, a relative majority of the respondents prefer democracy to authoritarian rule. This is tentatively good news, then: as long as support for non-democratic regime alternatives does not exceed support for a democratic polity, democracy may be deemed to have sufficient legitimacy among citizens, and the risk of a democratic breakdown must be regarded as small. At the same time, there is an obvious link between (perceptions of) poor performance and public support for democracy. In Estonia, we admittedly find quite a few disillusioned and indifferent respondents (Table 1); but also, the strongest democratic culture in the region (Table 2), a fact that may be explained with reference to successful political and economic performance. In Lithuania, and in particular in Latvia, political dissatisfaction is more common, and one could even question if democracy is indeed 'the only game in town' (Linz and Stepan 1996), when it comes to the Latvian respondents.

\section{LITERATURE}

Almond, Gabriel and Verba, Sidney, eds. (1980) The Civic Culture Revisited: An Analytical Study. Boston \& Toronto: Little, Brown \& Company.

Baltic Barometer (2014) Södertörn University, Stockholm.

Diamond, Larry (1999) Developing Democracy: Towards Consolidation. Baltimore: John Hopkins University Press.

Duvold, Kjetil (2006) Making Sense of Baltic Democracy. Örebro University: Örebro Studies in Political Science.

Duvold, Kjetil, Sten Berglund and Joakim Ekman (2019) Political Culture in the Baltic States: Between National and European Integration. Basingstokje and New York: Palgrave Macmillan. 
Easton, David (1965) A Systems Analysis of Political Life. New York, London and Sydney: John Wiley and Sons Inc.

Ehin, Piret (2007) 'Political Support in the Baltic States, 1993-2004'. Journal of Baltic Studies 38 (1), pp. 1-20.

Gerner, Kristian and Stefan Hedlund (1993) The Baltic States and the End of the Soviet Empire. London \& New York: Routledge.

Jurkynas, Mindaugas (2011) 'Lithuania' in Political State of the Region Report. Copenhagen: Baltic Development Forum.

Klein, Andreas, Ozolina, Zaneta and Rostoks, Tom (2011) 'Latvia' in Political State of the Region Report. Copenhagen: Baltic Development Forum.

Linz, Juan and Alfred Stepan (1996) Problems of Democratic Transition and Consolidation. Baltimore: The Johns Hopkins University Press.

Lühiste, Kadri (2008) 'Support for Strongman Rule in Ethnically Divided Societies: Evidence from Estonia and Latvia.' Democratization 15 (2): 297-320.

Lühiste, Kadri (2013) Regime Support in European Democracies. Tartu: University of Tartu.

Mattes, Robert and Bratton, Michael (2007) 'Learning about Democracy in Africa: Awareness, Performance, and Experience.' American Journal of Political Science, 51, pp. 191-217.

Norris, Pippa (1999) Critical Citizens Global Support for Democratic Governance. Oxford: Oxford University Press.

Rose, Richard, William Mishler and Christian Haerpfer (1998) Democracy and its Alternatives: Understanding Post-Communist Societies. Baltimore: Johns Hopkins University Press.

Rose, Richard (2005) Insiders and Outsiders: New Europe Barometer 2004. Studies in Public Policy 404, Univesity of Strathclyde, Glasgow: Centre for the Study of Public Policy.

World Migration Report (2018). Website: www.iom.int.

\title{
ДИСКУРСИВНЫЙ КОНСТРУКТ «ГИБРИДНАЯ ИДЕНТИЧНОСТЬ ТУРЕЦКИХ МИГРАНТОВ В ГЕРМАНИИ»: РЕКОНСТРУКЦИЯ И ОПИСАНИЕ
}

\author{
Е. И. Ядченко \\ Белорусский государственный университет, \\ 4, np. Независимости, Минск, 220030, Беларусь, jadtschenko@mail.ru
}

В своем материале автор обращается к проблеме изучения гибридной идентичности турецких мигрантов. Проведенное исследование выполнено в русле лингвистики дискурса и базируется на материале глубинных интервью с турецкими мигрантами, проживающими в Германии, а также скриптов телевизионных передач, ток шоу, включающих элементы интервью с турецкими мигрантами. Автор рассматривает идентичность мигранта как дискурсивный конструкт, репрезентирующий совокупность вербализованных в речи социокультурных характеристик, и предлагает возможности ее реконструкции лингвистическими методами.

Ключевые слова: дискурс мигрантов; дискурс-анализ; дискурс-категория; оценочность; значение; дискурсивное событие; коммуникативная стратегия.

\section{DISCOURSE CONSTRUCTION «HYBRID IDENTITY OF TURKISH MIGRANTS IN GERMANY»: RECONSTRUCTION AND DESCRIPTION}

\author{
E. I. Yadchenko \\ Belarusian State University, \\ 4, Nezavisimosti Ave., Minsk, 220030,Belarus, jadtschenko@mail.ru
}

In this article, the author addresses the problem of studying the hybrid identity of Turkish migrants. The study was carried out as part of the discourse linguistics and is based on in-depth interviews with Turkish migrants living in Germany, as well as scripts of television programs, talk shows, including elements of interviews with Turkish migrants. The author considers the identity 